\title{
Rozlúčenie s Eliášom Galajdom
}

\section{Viera Žemberová (Prešov)}

Rady slovenských rusistov sú skromnejšie. V prvej augustovej dekáde ich opustil vysokoškolský pedagóg Filozofickej fakulty Prešovskej univerzity, docent PhDr. Eliáš Galajda, CSc. (1. 8. 1931 - 10. 8. 2017). Rusistika medzi humanitnými odbormi na počiatku, od pätdesiatych rokov, na Univerzite Pavla Jozefa Šafárika a od devätdesiatych rokov na Prešovskej univerzite tvorí neprehliadnutel’né vzdelávacie a výskumné pracovisko, ktoré sa po dlhé roky spája s významnými osobnostami československého slavistického života.

Cesta za vzdelaním Eliáša Galajdu (Ilju Halajdu) bola určená jeho talentom a zanietenostou, bola tak dôsledne nasmerovaná aj uskutočnená, že niet prečo neuverit tomu, že sa mu rusistika spojila so všetkým, čím sa v profesijnom, autorskom a kultúrnom účinkovaní sprítomňoval v umeleckom a vedeckom živote medzi svojimi súčasníkmi a stovkami svojich študentov.

Vysokoškolské štúdiá ruštiny a ukrajinčiny začal na Karlovej univerzite v roku 1952, pokračoval v rusistických štúdiách do roku 1955 na Štátnej univerzite N. G. Černyševského v Saratove a ukončil ich v roku 1958 na Moskovskej štátnej univerzite M. V. Lomonosova.

Po štúdiách pracoval v redakciách periodík Dukl’a a Družno vpered, aby od roku 1960 až po dôchodok v roku 1990 spoluformoval jedinečné odborné zázemie Katedry ruského jazyka a literatúry na Filozofickej fakulte Prešovskej univerzity.

Docent Galajda sa venoval literárnej histórii, kmeňovo prednášal dejiny staroruskej literatúry, dejiny ruskej literatúry 19. storočia, dejiny ruskej kultúry. Literárnohistorický záber z genézy a vývinu ruskej kultúry a literatúry rozširoval o problematiku ruského konceptu literárnej vedy a folkloristiky. Z genologického výskumu ruskej literatúry vzišli práce Skazki Pushkiha: k probleme realizma skazok/ Puškinove rozprávky. K problematike realizmu rozprávky (1975) a neskôr Ruská autorská rozprávka od polovice 18 storočia až do polovice 19. storočia. Spoluautorsky pripravil v sedemdesiatych rokoch pre študentov ruského gymnázia Ruskú literatúru pre stredné školy.

Eliáš Galajda popri akademickom živote mal aj d’alšie dva komorné svety. Prvý patril básnikovi, prozaikovi, prekladatelovi. Druhý svet múzickému umelcovi, ktorý sa venoval tvarovaniu samorastov, predstavil ich verejnosti na autorskej výstave v Múzeu Andyho Warhola v Medzilaborciach v roku 1993, a hudbe, ktorá sa uchováva od roku 2001 v zázname Spivaje Ilja Halajda.

Autorská biografia Eliáša Galajdu je rozsiahla a druhovo členitá. V ukrajinskom jazyku publikoval od prvotiny Vosmero/ôsmi (1963) po poslednú Osinni refleksij/Jesenné reflexie (2011) jedenást’ básnických zbierok. Básnické zázemie pre svoju poéziu spájal s experimentmi básnickej formy, rád sa nechal inšpirovat folklórom. Báseň spájal s reflexiou, 
filozofovaním o prvých a posledných veciach a o dejoch ludského života. Eliáš Galajda nebol smutný básnik, bol básnik čertižianskej krajiny na východe Slovenska a tichých chvíl, ktoré sprevádzajú človeka po dobré i náročné dni jeho prítomnosti medzi blízkymi i vzdialenými. Nikdy, aj v strohosti svojich rozhodnutí, nebol lahostajný, a tak ho prijímali a cenili si ho jeho súčasníci. V roku 1980 vydal prozaickú prvotinu Koly idut’ došči Ked’ idú dažde a k nej pridal v roku 1989 prózu Šče spivaje žajvoronok/ Ešte spieva škovránok. Trvalým kultúrnym počinom sú antológie, ktoré autorsky zostavil. V roku 1995 antológiu poézie ukrajinských spisovatelov na Slovensku Soňačni krynyci a v roku 2007 Iz kuzni času, antológiu súčasnej slovenskej poézie preloženej do ukrajinčiny. V devätdesiatych a v prvom desat'ročí nového storočia preložil z ruštiny prózu B. Guimaraesa Izaura (1995) a do ukrajinčiny prózu J. Leikerta Pominutel'nost' (2006).

Autorskú tvorbu Eliáša Galajdu zostavovatelia pravidelne včleňovali do reprezentatívnych alebo profilových tlačí, medzi ne patrí Srdce ako slnce. Antológia poézie básnikov ukrajinskej národnosti v ČSSR (1982), pre českých čitatelov pripravené Ráno pod Karpatami. Výbor z poezie a prózy ukrajinských spisovateli̊ východniho Slovenska od roku 1945 (1983) a Korene. Antológia krátkej prózy autorov ukrajinskej národnosti v ČSSR (1990). Rešpekt a uznanie voči kultúrnym a odborným činom docenta Galajdu vyjadruje aj jeho členstvo vo Zväze spisovatelov Ukrajiny od roku 1995.

Dejiny literatúry a odborné príručky venované literatúre na Slovensku a jej tvorcom si uchovajú Eliáša Galajdu ako „slovenského spisovatel’a ukrajinskej národnosti“. Pri konečných dejoch spojených s tvorivým, láskavým a ústretovým, no predovšetkým rozhladeným človekom platí - a tým docent Galajda ostane v našej pamäti -, hoci ho nebudeme stretávat', bude s nami vždy, ked' sa začítame do jeho poézie a do statí venovaných poznávaniu a porozumeniu klasickému fondu ruskej literatúry a ruskej kultúry.

\section{prof. PhDr. Viera Žemberová, CSc.}

Inštitút slovakistiky a mediálnych štúdií

Filozofická fakulta, Prešovská univerzita v Prešove

UI. 17. novembra 1, 08000 Prešov, Slovensko

viera.zemberova@ff.unipo.sk 